\title{
Basic Principles of Simulations: In situ and Online Simulation
}

\author{
Biljana Stošić ${ }^{1,2}$, Ivana Budić1,2, Danijela Stankovićs, Marija Jovićc ${ }^{4}$, Velimir Perić1, \\ Marija Stošić ${ }^{1}$, Milica Radić ${ }^{1}$ \\ ${ }^{1}$ University of Niš, Faculty of Medicine, Niš, Serbia \\ ${ }^{2}$ Center for Anesthesiology, Clinical center Niš, Niš, Serbia \\ ${ }^{3}$ Health Care Center Negotin, Negotin, Serbia \\ ${ }^{4}$ Health Care Center Leskovac, Leskovac, Serbia
}

\section{SUMMARY}

Medical simulation is an artificial and a faithful representation of real clinical situations with the help of static and interactive doll simulators, standardized patients/actors, models for the exercise, simulation on a computer screen and a "serious" performance of a real clinical situation. That is a modern way of learning that helps students and health workers to achieve a higher level of expertise and provide a safer health care. Medical simulation is one of the greatest and most important innovations in medical education for the past 20 years. The goal of the simulation is to provide an optimal relationship between education and patient's safety. It is used both in undergraduate and postgraduate studies, as well as in continuing medical education. Simulators used in medical education can be divided into six groups, ranging from the use of paper and pencils to the most modern computerized interactive simulator. Depending on the economic development level and the organization of health care, rigorous high medical simulation can be performed in three ways: in the center for medical simulation, in the form of "in situ" simulation, and as remote simulations.

Key words: simulation, education, "in situ" simulation, "online" simulation

Corresponding author:

Biljana Stošić

Email: b.stosic@yahoo.com 


\section{INTRODUCTION}

Medical simulation is an artificial and a faithful presentation of real clinical situations, which is applied for the education of healthcare workers, using realistic clinical conditions on phantoms - puppets, models, standardized patients - actors and/or computers. The use of simulation in medical education provides the opportunity to acquire practical knowledge and skills without the risk of complications that could occur in real contact with patients. It can be used both for individual learning and practice and for dealing with a multidisciplinary team (1). The aim of the simulationbased medical education is to provide an optimal relationship between education (acquiring knowledge, skills and attitudes) of healthcare workers on the one hand and patient's safety (with respect to their ethical and legal rights) on the other hand (2). In addition, medical simulation has the potential to simulate a scenario that occurs in practice less frequently, such as emergency, critical and life-threatening conditions.

Medical simulation can be applied both in undergraduate and postgraduate studies as well as in the continuing medical education (CME) of healthcare workers for the reconstruction of critical situations, and emergency situations occurring in natural disasters and war.

\section{Classification of medical simulators}

All simulators can be classified in two different groups: according to their purpose and credibility. Classification of simulators by purpose:

Simulators can be divided in those for education by performing a certain procedure and those that perform certain clinical situations.

The classification of simulator by credibility:

The simplest form of simulation is to solve clinical problems using paper and pencil, or using a computer, writing papers in the case report form, using photos, available lab results, drug charts and lists of vital parameters (3).
Another form is the 3D simulation models static phantoms, life-size models or human body parts for low-fidelity simulations.

The third form of simulations are those which are performed using a computer software and a computer screen according to the type of computer graphic animation which can show physiological, pharmacokinetic and dynamic processes induced by administering certain drugs (3).

The next level of simulators is the so-called "standardized or simulated patients". These are usually trained performers - actors who simulate different clinical conditions and diseases, who communicate with students relying on the medical history and certain segments of the physical examination, which leads to the diagnosis of the diseases that they simulate (4).

A higher level of simulation includes computer-controlled and programmed simulators with semi-interactive approach. It allows the acquisition of cognitive, psychomotor and interpersonal skills and experience. It requires the existence of a simulation center or in situ simulation. The knowledge acquired is similar to the previous level with the adoption of invasive skills and techniques depending on the designed scenarios. For such a scenario, sophisticated programs should be used, students should be acquainted with the equipment, and education and practice are possible only in small groups (3). These simulator groups include the ultrasound simulators and automated external defibrillator (AED) with instruction manual. Minimally invasive surgical procedures can be performed by different simulation systems, and they require from surgeons to acquire new knowledge continuously. In the field of endoscopy, similar techniques are used in the areas of gastroenterology, bronchoscopy, and artroscopy; therefore, developed simulators in these areas are used for training (5). 
The highest level of simulations is interactive computerized patient simulators. In addition to computer equipment and software, they demand audio and video equipment. Highly reliable patient simulators are sensitive, expensive and difficult to transport. They enable the most realistic view of the clinical situation through the so-called "virtual reality" (6). This level of simulation requires the existence of a well-equipped simulation centre with the control room. It can also be applied in a variety of clinical settings - in situ simulation (reanimation clinic, intensive care unit, operating room). Highly authentic simulators use the whole phantom body that acts like a real patient with a possibility to talk to students, until they "lose consciousness", and a possibility to breathe. In addition, monitoring of lung function parameters and pulse is feasible as well, so students can measure blood pressure, auscultate heart beats and respiratory noise. These simulators can also measure diuresis, there is a possibility of moving the eyelids, the pupils response to the light source, tracheal intubation can be performed, CVC line placement, performing of thoracic drainage etc. It enables the monitoring of neuromuscular transmission by using classical nerve simulators, simulation of compartment limb syndrome, followed by computer-guided types of ventilation. Heart rate can be transferred to the patient's monitor. The administration of the anesthetic drugs, from gases to vasopressin, narcotics, muscle relaxants and infusion solutions leads to an adequate physiological response depending on the programmed sex, age and weight of the phantoms' body. The level of training and involvement in the clinical problem can be increased by creating a real work environment, such as ICU simulation, or the operating room simulation, with the possibility of video recording scenarios in order to evaluate and improve the performance of manual skills and techniques during training.

\section{Spacious, technical and personnel organization of simulation in medicine}

In the developed European countries, almost every hospital or medical teaching institution has a developed system of education based on simulation. In the last 20 years, it is almost unthinkable to conduct training of medical students and health professionals without some of the previously mentioned simulation techniques and methods (7). Depending on the economic development, environment, and the level and health care organization, training programs are being planned in medical schools and health institutions.

\section{Center for simulation}

The development of simulation centers is a global phenomenon which needs to be adapted to the curricula which are methodologically feasible and economically viable. Usually, they are part of medical faculties, schools and health institutions. In addition to the necessary equipment, which includes models mannequins of various degrees of fidelity, computers, audio/video equipment, adequate space is also necessary (8). The simulation center should have a classroom to prepare university students for certain scenarios, a teaching unit, at least one room for simulation (simulation intensive care units, resuscitation rooms or operating rooms) and a command room with transparent partition associated with the room for the simulation (9).

Simulation center of the Faculty of Medicine in Niš has emerged as a result of the need for a modern method of education of students of medicine, dentistry and nursing care in various areas of emergency clinical conditions with situations that do not happen frequently in real terms during the study. It consists of an introductory lecture hall with 30 seats with computer equipment, offices for administrative needs and instructors' preparation, a base room, a control room, a room for simulation, two bathrooms and storage space for equipment. The equipment consists of: HAL S3201 or 3101 (2 mannequins), Noelle S550.100 (1 mannequin), 
Code Blue III Pediatric S300.105 (1 mannequin), HAL S315.200 Adult Heart and Lung Sounds (1 mannequin), Laerdal MegaCode Kelly (1 mannequin), Laerdal ADL Infant (1 mannequin), Laerdal Airway Management Trainer (1 mannequin), Choking Charlie (1 mannequin), Laerdal AED trainer 2 (1 mannequin), Manual defibrillator Zoll (1 mannequin), Male Multi-Venous IV Training Arm Kit (1 mannequin), Arterial Arm Stick Kit (1 mannequin), Pneumothorax Trainer (1 mannequin), Laerdal Infant Airway Management Trainer (1 mannequin), Laerdal Neonatal Intubation Trainer (1 mannequin).

In the simulation room, a central role is given to a mannequin placed in a hospital bed, connected to a monitor. The mannequin simulates monitoring of ECG, systolic and diastolic blood pressure, and pulse rate. A central venous catheter (CVC) is connected to infusion solutions and systems for measuring the central venous pressure (CVP). In addition, there is a possibility of measuring hourly urinary output, transfusions administration and blood products administration.

The audio equipment is installed in phantoms and it provides the auscultation of heart sounds as well as the breathing sounds. There is a possibility of simulating the CPR, cardiology emergencies, cardiac rhythm disturbances, pulmonology emergencies, thoracic surgery and pediatrics emergencies. It is possible to simulate pneumothorax, pleural puncture and active drainage. Laboratory analyses are displayed on a monitor immediately after the administration of certain therapy. Besides a manual defibrillator, an automatic external defibrillator is part of the equipment, too. We are currently collaborating with the Faculty of Technical Sciences, University of Nis as we need a specific computer programs adapted to our equipment that should simulate various emergency clinical conditions.

\section{In situ simulation}

While simulation is becoming more and more popular in the field of medical education, a major problem in some schools and some health institutions is how to organize simulation exercises without the existence of the centers for simulation that are not available yet, primarily due to the high cost (10). Therefore, many health care facilities which are dealing with education use the model of mobile training of medical workers with the help of the equipment that they use every day, without costly and technologically demanding centers for simulation. This is a so-called in situ simulation (11). Its advantage, in addition to the economic factors, is more humane and more relaxed approach to the medical staff who are educated in their well-known daily work environment, but also a possibility of perceiving the real flaws in the health care system in real conditions. In fact, in situ simulation allows healthcare professionals to learn and develop experience in the same place where their patients are treated, to apply their knowledge and use their experience to ensure the best treatment of patients. It has been proven that the simulation in situ enhances teamwork and communication during the care of trauma (12). Teteris et al. showed that in situ simulation improves a response of the team for emergency care of pediatric patients whose condition is deteriorating (13).

Mobile in situ simulation requires the presence of an instructor as a member of the team. The entire equipment is very important as it brings the benefits of the training in real conditions. Simulation sessions can also be performed in prehospital conditions, in an ambulance or a helicopter (3).

\section{Advantages and challenges of in situ simulation}

The main advantage of in situ simulation is the absence of the need for a permanent location. The only thing you need is a place to store the material at the time when it is not in use. Another advantage in terms of learning is that the whole system in a random environment could be included in training and be tested by its own equipment in daily work. Salas et al. propose that the CPR session should be practiced by nursing teams every month (14). Brydges et al.'s study suggests that the simulation sessions for emergencies need to be maintained for dentists. In situ simulation can be used to implement new treatment protocol in order to ensure their applicability and find a potential problem that has not been previously observed (15). From this type of simulation is expected that the whole team of participants should be released from work duties during the training. In practice, this is sometimes difficult to achieve, especially in the emergency departments. 


\section{Remote-facilitated simulation}

Simulation training is not available in many institutions and there is often a lack of trained instructors, which represents a barrier to the development of this type of education. The high price limits some medical institutions to develop modern centers for simulation (16).

Owing to modern computers, up-to-date electronic and communication technologies, it is possible to provide remotely controlled simulation-based learning, the so-called "remote-facilitated simulation" (4).

Remote simulation command requires the existence of a simulation center that manages simulations that can be organized in remote areas, hundreds of kilometers away. This course requires sophisticated equipment, computers, software, and audio and video equipment. Computer equipment from the command center is connected to the highly faithful simulators in a simulated unit, and instructors from the command center monitor the students' work, and communicate with them via webcam and microphone. By using this system, the remote control can be used as an operating simulator that provides simulation training of students and final evaluation of their knowledge and skills (17).

Once purchased equipment and software with a developed network in situ simulation and a small number of well-trained instructors could cover large regions. This centralized approach allows a uniform system of education to enormous number of health workers.

\section{CONCLUSIONS}

The application of simulation is one of the largest and most important innovations in medical education for the past twenty years. Quite often, many people associate it with the sophisticated equipment that costs a lot and is often unattainable in conditions of insufficient funding. In this article we have shown in our example that this is possible in resource-limited settings as well. With enthusiasm, creativity and good ideas it is possible to obtain satisfactory results in the field of medical simulation, with the tendency of further development and integration with advanced simulation centers in Europe and the world. Events such as the formation of a large number of academic associations dedicated to the medical simulation, the existence of several journals of medical simulation, obtaining large financial resources from the national research centers for the medical simulation development, and continuous researches in this field are good basis for the further development of medical simulation. These facts are aimed at the education of students and healthcare workers and increasing patient safety as well. 


\section{References}

1. Rashmi D. at al: Simulation and its role in medical education. MedJ Armed Forces India 2012; 68(2):167-72

https://doi.org/10.1016/S0377-1237(12)60040-9

2. Hssain I, Alinier G, Souaiby N. In-situ simulation: A different approach to patient safety through immersive training. Mediterranean JEmerg Med 2013 15;(15):17-28

3. Rosen MA, Hunt EA, Pronovost PJ, Federowicz MA, Weaver SJ. In situ simulation in continuing education for the health care professions: a systematic review. J ContinEduc Health Prof 2012;32:243-54.

https://doi.org/10.1002/chp.21152

4. Ikeyama T, Shimizu N, Ohta K: Low-cost and ready-to-go remote-facilitated simulation-based learning. SimulHealthc 2012;7(1):35-9. https://doi.org/10.1097/SIH.0b013e31822eacae

5. Harry O. Early use of simulation in Medical Education. SimulHealthc 2012;7(2):102-16. https://doi.org/10.1097/SIH.0b013e3182415a91

6. Bradley P. The history of simulation in medical education and possible future directions. Med Educ 2006;40:25. https://doi.org/10.1111/j.1365-2929.2006.02394.x

7. Ziv S, Small P, Root W: Patient safety and simulation-based medical education. Med Teach 2000;22(5):489-95.

https://doi.org/10.1080/01421590050110777
8. Hssain I, Alinier G, Souaiby N. In-situ simulation: A different approach to patient safety through immersive training. Mediterranean JEmerg Med 2013 15;(15):17-28.

9. Issenberg SB, McGaghie WC, Petrusa ER, Lee GD, Scalese RJ. Features and uses of high-fidelity medical simulations that lead to effective learning: a BEME systematic review. Med Teach 2005;27:10-28.

https://doi.org/10.1080/01421590500046924

10. McGaghie WC, Issenberg SB, Petrusa ER, Scalese RJ. A critical review of simulation-based medical education research: 2003-2009. Med Educ 2010; 44:50-63.

https://doi.org/10.1111/j.1365-2923.2009.03547.x

11. Motola I, Devine LA, Chung HS, Sullivan JE, Issenberg SB. Simulation in healthcare education: a best evidence practical guide. AMEE Guide No. 82. Med Teach 2013;35: 1511-30. https://doi.org/10.3109/0142159X.2013.818632

12. McGaghie WC, Issenberg SB, Barsuk JH, Wayne DB. A critical review of simulation-based mastery learning with translational outcomes. Med Educ 2014;48:375-85.

https://doi.org/10.1111/medu.12391

13. Teteris E, Fraser $\mathrm{K}$, Wright $\mathrm{B}$, McLaughlin $\mathrm{K}$. Does training learners on simulators benefit real patients? Adv Health SciEduc Theory Pract 2012;17:137-44.

https://doi.org/10.1007/s10459-011-9304-5 
14. Brydges R, Hatala R, Zendejas B, Erwin PJ, Cook DA. Linking simulation-based educational assessments and patient-related outcomes: a systematic review and meta-analysis. Acad Med 2015;90:246-56.

https://doi.org/10.1097/ACM.0000000000000549

15. Salas E, Paige JT, Rosen MA. Creating new realities in healthcare: the status of simulationbased training as a patient safety improvement strategy. BMJ QualSaf 2013;22:449-52.

https://doi.org/10.1136/bmjqs-2013-002112

16. Cook DA, Hamstra SJ, Brydges R, Zendejas B, Szostek JH, Wang AT, Erwin PJ, Hatala R.
Comparative effectiveness of instructional design features in simulation-based education: systematic review and meta-analysis. Med Teach 2013;35: 867-98.

https://doi.org/10.3109/0142159X.2012.714886

17. Sollid SJ, Dieckman P, Aase K, Soreide E, Ringsted C, Ostergaard D. Five Topics Health Care Simulation Can Address to Improve Patient Safety: Results From a Consensus Process. J Patient Saf 2016.

https://doi.org/10.1097/PTS.0000000000000254 


\title{
Osnovni pricipi simulacije: In Situ i Online simulacija
}

\author{
Biljana Stošić1,2, Ivana Budić1,2, Danijela Stankovićc ${ }^{3}$, Marija Jović4, Velimir Perić1, \\ Marija Stošić1 , Milica Radić ${ }^{1}$
}

\author{
${ }^{1}$ Univerzitet u Nišu, Medicinski fakultet, Niš, Srbija \\ ${ }^{2}$ Centar za anesteziologiju, Klinički centar Niš, Niš, Srbija \\ ${ }^{3}$ Zdravstveni centar Negotin, Negotin, Srbija \\ ${ }^{4}$ Zdravstveni centar Leskovac, Leskovac, Srbija
}

\begin{abstract}
SAŽETAK
Simulacija je veštačko predstavljanje realnih kliničkih situacija pomoću statičke i interaktivne lutke-simulatora, standardizovane bolesnike/glumce, modele za vežbanje, simulacije na ekranu kompjutera i „ozbiljno “ izvođenje realnih kliničkih situacija. To je moderan način učenja koji omogućava studentima i zdravstvenim radnicima da postignu viši stepen edukacije i obezbede najbolju zdravstvenu zaštitu. Simulacija predstavlja najveću i najvažniju inovaciju u poslednjih dvadesetak godina u medicinskoj edukaciji. Cilj medicinske simulacije je da obezbedi adekvatan odnos između obrazovanja studenata i bezbednosti bolesnika. Ima primenu kako u svim etapama edukacije studenata tako i u kontinuiranoj medicinskoj edukaciji. Simulatore koji se koriste $\mathbf{u}$ edukaciji možemo podeliti u šest grupa, uzmajući u obzir one koji za osnovu imaju papir i olovku, do najsavremenijih kompjuterizovanih interaktivnih simulatora. Medicinska simulacija može se izvesti na tri načina: $u$ Centru za medicinsku simulaciju, u vidu simulacije "in situ" i simulacije na daljinu.
\end{abstract}

Ključne reči: simulacija, edukacija, "in situ" simulacija, "online" simulacija 